\title{
ЛЕКСИЧНІ АРХАЇЗМИ У ТВОРЧІЙ СПАДЩИНІ ІВАНА НЕЧУЯ-ЛЕВИЦЬКОГО
}

Колоїз Ж. В. Лексичні архаїзми у творчій спадщині Івана Нечуя-Левицького.

У статті йдеться про різні тематичні (лексико-семантичні) поля і групи лексичних (матеріальних і стилістичних) архаїзмів, репрезентовані творчою спадщиною І. НечуяЛевицького, які віддзеркалюють передусім історичні та культурні надбання українсь- 
кого народу. Вивчення лексичних архаїзмів на матеріалі художнього доробку письменника розглядається як таке, що сприятиме збагаченню словникового запасу учнів, кращому розумінню програмних творів.

Ключові слова: лексичний архаїзм, матеріальний архаїзм, стилістичний архаїзм, застаріла лексика.

Колоиз Ж. В. Лексические архаизмы в творческом наследии Ивана Нечуя-Левицкого.

В статье рассматриваются разные тематические (лексико-семантические) поля и группы лексических (материальных и стилистических) архаизмов, репрезентированные творческим наследием И. Нечуя-Левицкого, которые отображают прежде всего исторические и культурные достояния украинского народа. Изучение лексических архаизмов на материале художественного наследия писателя способствует обогащению словарного запаса учеников, лучшему пониманию программных сочинений.

Ключевые слова: лексический архаизм, материальный архаизм, стилистический архаизм, устаревшая лексика.

Koloiz Sh.V. Lexical archaisms in the creative legacy of J. Nechuy-Levitsky.

The article presents different thematic (lexical-semantic) fields and graups of lexical (material and stylistic) archaisms, represented by creative legacy of J. Nechuy-Levitsky, which first of all reflect historical and cultural heritage of Ukrainian people. The studing of lexical archaisms on the material of fiction legacy of writer is considered as that, which assists with enrichment of pupils lexicon, better understanding of syllabus compositions.

Key words: lexical archaisms, material archaisms, stylistic archaisms, old lexicon.

Лексика української мови, як відомо, на основі активного / пасивного iї використання в повсякденному спілкуванні традиційно диференціюється на два основні різновиди, відповідно, активну та пасивну. До останньої зараховують здебільшого слова, якими носії тієї чи тієї мови не послуговуються взагалі або послуговуються лише з певними, переважно стилістичними, інтенціями. Така лексика набула статусу застарілої, оскільки вийшла з ужитку, не задовольняє вимог і потреб сучасної комунікації, інакше кажучи, відійшла на периферію лексичної системи. У науковій літературі застарілі слова кваліфікують як лексичні архаїзми [1, 264] (від грецьк. archaios - давній, старовинний).

Лексичні архаїзми - це слова або сполучення слів, які активно функціонували на певному етапі розвитку мови, репрезентували в конкретній звуковій матеріальній формі вираження життя, побут, соціальну належність і т. ін. іiі носіїв, однак із часом утратили свою актуальність і активність у зв'язку з суспільним прогресом (передусім соціальними, політичними та виробничими змінами). Відповідно до твердження Е. Косеріу, у функціональному плані архаїзми як елементи, здатні надавати мові архаїчного забарвлення, є такими лише з погляду сучасної мови, адже в попередні епохи вони не могли виконувати цієї функції [4, 149]. Попри те, що лексичні архаїзми складають пасивний словниковий запас носіїв мови, віддалені на периферію лексичного складу у зв'язку з їхньою номінативною неактуальністю, спричиненою втратою (частковою або повною) суспільної ваги відповідними конкретними реаліями, явищами, процесами, шкільні 
програми передбачали, передбачають i, сподіваємося, передбачатимуть години на опанування цією складною категорією одиниць.

Поява лексичних архаїзмів спричинена постійними процесами старіння певної частини словникового складу, зумовленими як зовнішніми, так і внутрішніми чинниками розвитку мови загалом $[11,231]$. Адже, безперечно, у кожного слова, що тепер воно отримало статус застарілого, була власна історія виникнення, становлення, прийняття узусом, стабілізації, активного використання i, врешті-решт, архаїзації. Вони „віджили” термін, після якого втратили свою актуальність, поступово почали „зникати 3 історичної пам'яті”, потреба в їхній активній відтворюваності відпала сама по собі. А відтак можна з упевненістю сказати, що лексичні архаїзми - це відгомони давнини, відголоски колишніх славних (і не дуже!) історичних подій, „відзвуччя живоття” наших дідів і прадідів. Застарілі слова пасивно, час від часу, при нагальній потребі використовуються мовцями і то здебільшого лише тими, які, послуговуючись ними, намагаються реалізувати певні прагматичні завдання. До такої категорії належать передовсім письменники.

У цьому плані заслуговує на увагу творча спадщина видатного митця, представника класичної літератури XIX століття Івана Нечуя-Левицького, який ,увійшов в українську літературу з власною неповторною манерою письма, спираючись на народну мову і водночас сміливо трансформуючи iii, що виявилося у введенні в обіг лексики і фразеології різних соціальних груп i прошарків, у поєднанні суто народних, інколи розмовнофамільярних елементів із книжними, в активному формо- і словотворенні" $[5,110]$ і перу якого судилося зареєструвати, увіковічнити розмаїтий ряд лексичних архаїзмів, пов'язаних насамперед із повсякденним життям, побутом, народними звичаями простого селянина дореволюційної доби.

Лексичні архаїзми, засвідчені в мовотворчості видатного класика, досить строкаті у структурно-семантичному та функціонально-стилістичному аспектах. Відповідно до традиційної класифікаційної схеми 3-поміж слів, яким надано статус застарілих, чітко виокремлюються два основні різновиди: а) матеріальні архаїзми, або історизми; б) стилістичні архаїзми, або власне архаїзми. Інтегральними їхніми ознаками $\epsilon$ те, що, по-перше, обидва типи зазнали процесу архаїзації; по-друге, й історизми, і власне архаїзми перебувають на периферії вживання; по-третє, і перші, i другі можуть бути охарактеризовані як пасивна лексика. Щодо їхньої диференціації, то, слід зауважити, вона пов'язана передусім з функціональними особливостями.

Матеріальними архаїзмами, або історизмами, називають слова, якими послуговувалися для позначення предметів, явищ, процесів і т. ін., пов'язаних із минулим і зовсім неактуальних для сучасних носіїв мови, тобто такі, що вийшли з ужитку, припинили своє існування у зв’язку з суспільним прогресом. Наприклад: B екіпажі сидів військовий з полковницькими еполетами [6, 349], де еполети - „парадні офіцерські погони з гаптуванням у дореволюційній російській та деяких іноземних арміях" $[2,266]$; $M u$ - 
кола ще більше зажурився, бо за померлого батька треба було платить подушне як за живого, доки не вийде нова ревізія [6, 457], де подушне „стягування з кожної душі податного стану” [2, 825], ревізія - „перепис населення, що повинно було платити подушну подать і відбувати рекрутську повинність" [2, 1019]; Пан почав знов одлічувати згінні дні та мирварки саме в жнива, а не восени [6, 459], де шарварок - „додаткова до панщини феодальна повинність із будівництва i ремонту мостів, шляхів, гребель, панських будинків і т. ін” [2, 1389]; В Скрипчиниях вже ловили некрутів $i$ забивали в колодки [6, 461], де некрут (рекрут) - „солдат-новобранець” [2, 1024], колодки - ,масивні дерев’яні кайдани, що їх за старих часів надівали на ноги, руки і шию заарештованому" (пор.: диба [2, 220]). Основне функціональне призначення проілюстрованих матеріальних архаізмів полягає в тому, аби репрезентувати відповідну назву колишніх історичних реалій, тобто вони виконують здебільшого функцію номінації. Їхня матеріальна форма вираження залишилася лише в ,історичній пам'яті” сучасних носіїв мови й вибирається звідти при потребі.

До стилістичних архаїзмів, або власне архаїзмів, зараховують одиниці, які можна кваліфікувати як ,застарілі синоніми до відповідних за значенням слів сучасної української мови, що перебувають в активному вжитку" [11, 239], тобто вони вийшли з ужитку внаслідок витіснення синонімами. На відміну від історизмів 3 властивою їм безпосередньою номінативною функцією, власне архаїзми використовуються задля створення відповідного стилістичного ефекту, емоційно-експресивного забарвлення, розраховані на забезпечення історичного колориту. Наприклад: $B$ духівниці не так написано [6, 167], де духівниця - ,заповіт про спадщину” [2, 252]; На возі сокири не кидай, бо щзе хтось вночі почупить та й на торжск однесе [6, 355], де торжнок - „ринок, базар” [2, 1257]; Батюшка у Вербівці був молодий і вже нагнав плату за треби вдвоє [6, 449], де треби - ,релігійний обряд (хрестини, вінчання, панахида тощо), що його здійснював священик на замовлення вірян” [2, 1264]; Старі люди гомоніли, щуо треба ї̈ вивести на дзвіницю та вибити посторонками од дзвонів або, по давньому звичаю, забити на ніч у цееркву в куну, замкнувши руку залізною дужкою, прибитою до стіни [7, 64], де посторонок - „міцний ремінь або мотузок” [2, 899], куна - ,залізна скоба прибита у церкві, у яку вкладали руку жінки, караючи іiі за порушення правил пристойності” [2, 473]; Коли хоч, я напишу до його квит, дам тобі до рук, $і$ він тебе прийме, хочеш у сахарню, хочеш на суконну фабрику [7, 66], де квит - ,записка" [2, 423]; Регент хора Билінський, ігуменів небіж, послушник в монастирі, розпочав співки хора, щуоб повиучувати напам'ять старовинні канти й пісні, щзоб співати їх для розваги вчителів та й школярів [8, 232], де кант - „хвалебна врочиста пісня духовного або світського змісту" [2, 413];... наші школярі, сливе усі, клеїли самі для себе дуже гарні пірники з паперу, щзоб не носити в клас пер в книжках [8, 239], де пірник - „те саме, що пенал” [2, 789] тощо. Більшість 
стилістичних архаїзмів мають старослов'янське (церковнослов'янське) походження, їхні первинні значення частково відрізнялися від тих, які ілюструють вищенаведені контексти (наприклад, у церковнослов’янській мові лексема треба означала „жертвоприношення”), деякі 3 них вступають у синонімічні відношення не лише зі словом, яке, по суті, витіснило архаїзм зі слововжитку, але й з іншими архаїчними одиницями (наприклад, торжсок < тържньъ і торжнице ‘ тържсище - „майдан, ринок”).

Будь-яка підсистема, як i система взагалі, передбачає взаємопов'язаність своїх елементів. Лексичні архаїзми як елементи лексичної підсистеми мовної системи також певним чином взаємопов'язані, що дає змогу говорити про системні відношення в межах окремої групи слів. Відповідно до семантичних особливостей лексичні архаїзми (i матеріальні, i стилістичні) об’єднуються на основі спільності родових ознак у такі тематичні (лексико-семантичні) поля:

1. Назви, що характеризують класову структуру суспільства, соціальний стан, місце людини в суспільстві та суспільні взаємовідносини представників різних верств населення в минулому: ... як блискавка, мигнула в його голові думка про Миколу й вербівських бурлак [6, 472], де бурлака „людина без постійної роботи і постійного місця проживання" [2, 67]; Бжсозовський задумав другого дня з сільською полічією половить своїх кріпаків $і$ вернути додому [6, 472], де кріпак - „особисто залежний від поміщика й прикріплений до земельного наділу селянин” [2, 466]; Ястшембський зараз надійшов в пекарню і звелів Одарщзі мерщзій видати полудень че-

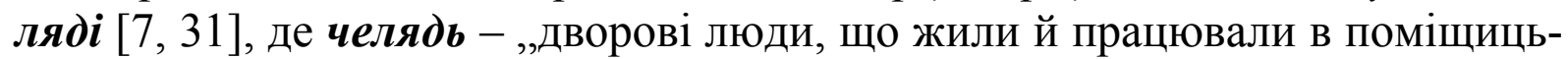
кій садибі; панська прислуга" [2, 1373]; Прийшла вчора така бумага, щзоб ти виряджала свого сина в школу, бо він, бач, ніби солдатський син, значиться кантоніст [6, 64], де кантоніст - „солдатський син, що від народження приписувався до військового відомства, навчався у спеціальній військовій школі та відбував тривалу військову службу" [2, 414]; Вони знали академістів по проповідях у Братському монастирі, а найбільше в $n$ 'ятницю великого посту, коли збирались на пасію сотні киян $[6,123]$, де академіст - „студент академіі” [2, 10];

2. Назви державного і політико-економічного устрою: Саме в той час прийшов з синода „указ”, щзоб оддавали дітей в духовні училищза в вісім год [8, 205], де синод - ,у дореволюційній Росії - найвищий колегіальний орган Руської православної церкви” [2, 1123]; Деякі були послані на скарбові гроші в Київську духовну академію [6, 101], де скарбовий < скарб (скарбниця) - „урядова установа, що відала державними коштами " [2, 1133], тобто скарбові гроші буквально означає „державні гроші”; Він бачив такі книжечки в тяжку годину свого життя, як його сина в некрути брали, як його ганяли на панщину ц̌ записували панщанні дні $[6,279]$, де панщина - ,дарова примусова праця покріпачених селян у господарстві поміщика" [2, 703], панщцанні дні - „дні, у які панщанник (селянин) відро- 
бляв панщину" [2, 703]; Вона почала думать про свою смерть, наготувала собі сорочку й намітку, придбала грошей на похорон, на подзвінне, на євангелію [6, 517], де подзвінне - „плата дзвонареві за похоронний дзвін” [2, 822]; А тут було прийде строк платить панові чинш за оту дерезу [6, 87], де чинш - „натуральний або грошовий податок, що його платили поміщикам" [2, 1378];

3. Назви урядових і адміністративних посад: Над ворітьми блиснули вирячкуваті неласкаві сірі очі. То був осавула [6, 439], де осавула - „прикажчик у панському маєтку" [2, 681]; Йому заманулось піти до неї, хоч ласкаве слово промовить, хоч подивитись на неї, та гуменний стовбичив над душею [6, 453], де гуменний - „прикажчик, що організовував роботу на току поміщика" [2, 201]; Саме в той час Мокрина з матір'ю продавала на базарі рибу, бачила всю ту комедію й прочула, щзо становий готується тієї ночі набігти з десяцькими на батькову ватагу й половити усіх бурлак [6, 505], де становий - „служитель адміністративно-поліцейського підрозділу повіту” [2, 1188], десяцький - „нижчий поліцейський служитель на селі, якого обирали селяни" [2, 217];

4. Назви адміністративних установ та організацій: Тим часом на селі завелись нові порядки; вже завели волость [6, 532], де волость - ,адміністративно-територіальна одиниця, що входила до складу повіту" $[2,156] ;$ Пан звелів привести їх усіх увечері на економію [6, 455], де економія - „поміщицьке господарство капіталістичного типу" [2, 256]; Бродовський, взявии в посесію сахарні, довго морочивсь, поки привчив людей казати йому „ви” [6, 478], де посесія - „переданий в оренду державний маєток, мануфактура" [2, 890], сахарня - „цукровий завод”; Часом один хазяїн мав два або й три таких курені $і$ наставляв на кожний курінь опрічного отамана $[6,498]$, де курінь - ,житло козаків, які складали таку частину війська” [2, 474];

5. Назви осіб за виробничою діяльністю: Найняв хурмана, та не всі гроші заплатив: треба доплатити один карбованець [6, 67], де хурман „візник” [2, 1356]; Старі жиди й жидівки бродять, мов ті чаплі, сливе по коліна в грязі; жиденята хлюпаються, як поросятка, а сидухи та перепічайки з бубликами, з варивом сидять на горбиках [6, 80], де сидуха - ,жінка, що займалася дрібною приватною торгівлею на ринку або на вулиці" [2, 1119], $\boldsymbol{n}$ репічайка - „жінка, яка випікала хліб” [2, 739]; В той час як вербівські бурлаки розмовляли з робітниками, надійшов сам посесор [6, 477], де посесор „власник посесійного підприємства” [2, 890]; 3 отаманом сів в човні кодільничий та кілька рибалок [6, 498], де кодільничий - „канатник; рибалка, що тягнув канат (кодолу) під час витягання невода" [2, 438]; Отаман полюбив Миколу й поставив його за крилаша [6, 514], де крилаш - „помічник рибальського отамана" [2, 464]; Політники посовувались по буряках все далі та далi [7, 11], де політник - „той, хто наймався на літні роботи” [2, 849];

6. Назви народних звичаїв, традицій, розваг: Перед вечором прийшов молодий з боярами, свашками та світилками [6, 450], де боярин - „,това- 
риш молодого, який є головним розпорядником на весіллі” [2, 61], свашка - „жінка, яка добре знаючи весільні обряди, порядкувала на весіллі” [2, 1105], світилка - ,дівчина, що виконувала обряд тримання меча й свічки на весіллі" [2, 1108]; ... в католиків причащзаються не вином та проскурою, а облатками [8, 226], де облатка - „тоненький прісний коржик із борошна, спечений на вині, для причастя в католиків i протестантів" [2,640]; А хлопиі, взявшись в боки, закинувши щапки набакир, то підуть навприсядки, то задріботять ногами, то вдарять тропака [6, 40], де тропак - „народний танець, за характером виконання близький до гопака" [2, 1270]; Дивлюсь я, чужі діти бігають, гуляють в иіиі-баби, в хрещцика, купаються, а мені не можна й одступитися від дітей [6, 443], де хрещик - ,рід гри, у якій одна пара гравців ловить іншу” [2, 1353]; Деякі покидали недоӥдену страву, бігцем кинулись до музик і розпочали метелицю $[7,11]$, де метелиця - „народний танець, виконуваний у швидкому темпі, з частими змінами фігур" [2, 521]; Вивчивщи свої уроки, кидались на грання в деякі забавки: іграли в мети, гилки, свинки [8, 213], де гилка „давня народна гра в м’яч” $[2,180]$, свинка - „гра, під час якої намагаються палицею загнати дерев’яну кульку в ямку” [2, 1106];

7. Назви транспортних (сухопутних i водних) засобів пересування: Коні забігли дуже прудко на греблю, $і$ балагула засіла в грязь по самісінькі маточини [6, 179], де балагула - „критий дорожній віз” [2, 34]; Десь узялись ножі й виделки, сільничка й чарки, неначе вони прилетіли з Масюківки слідом за шарабанами і впали на стіл [6, 358], де шарабан - „старовинний чотириколісний екіпаж 3 поперечними кількарядними сидіннями" [2, 1389]; Четверня добрих коней несла легенький фаетон ніби на руках [6, 474], де фаетон - „легкий чотириколісний екіпаж із відкритим верхом” [2, 1313]; Проти неї виїхала з пшениці бідка [7, 66], де бідка (біда)- „двоколісний однокінний візок на одну або дві особи" [2, 50]; Кілька дубів $і$ берлинок з кавунами простувало по Дніпрі до пристані [6, 307], де дуб - „великий човен, видовбаний із суцільного дерева (переважно дуба) або зроблений 3 дощок” $[2,250]$, берлинка - „велике річкове плосководне вантажне судно; барка" [2, 48]; Аж за Дніпром на берегах горіло багаття й освічувало щзогли байдаків: то білоруси варили вечерю [6, 305], байдак - „великий човен, яким плавали по річках і морю" [2, 33];

8. Назви одягу та взуття: Ти думаєш, як начепив ж⿻упана та зав'язав шию хусткою, то й до Онойка можна лізти з старостами [6, 247], де жупан - ,верхній чоловічий одяг, оздоблений хутром і позументом, що був поширений серед заможного козацтва та польської шляхти" [2, 278]; Я аж злякалась, як одна купчиха скинула мантиль [6, 212], де мантиль (мантилья) - „коротка жіноча накидка без рукавів” [2, 509]; Вони були позавірчувані в шуби, в бурнуси, в кохти, в товсті хустки та хусточки, як єгипетські мумї [7, 51], де бурнус - „просторе жіноче пальто з широкими рукавами" $[2,68]$; По одежі й по убранні ия громадка була схожа на збір се- 
лянських хлопчаків з паничами: половина їх була одягнута в козини (чемерки), одна частка була одягнута в сіртучки та халатики [8, 206], де козин, чемерка - „верхній чоловічий одяг, пошитий у талію з фалдами ззаду” [2, 1373], сіртучок (сюртук) - „верхній чоловічий двобортний одяг із довгими полами, відкладним коміром і широкими лацканами" $[2,1225] ; y$ батька зостався на стіні тільки праотецьь Ной з трьома бородатими синами та якась цариця в фіжсмах, дуже залякана муками [6, 145], де фіжс-

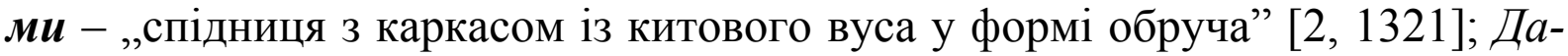
вайте й справді будемо смішить ваших сільських „хахлів та хахлушок”, оті очіпки та очкури [6, 407], де очіпок - „старовинний головний убір заміжньої жінки у формі шапочки, часто з поздовжнім розрізом ззаду, якого зашнуровували, стягуючи сховане під ним волосся” [2, 694], очкур - „пояс або шнур, яким стягували штани або шаровари для їхнього підтримання" [2, 694]; На їх обох були турецьькі феси з червоного оксамиту, з золотими китицями [6, 105], де фес (феска) - „шапочка, звичайно червона, зрізаного конуса $з$ китицею” [2, 1319]; Серб ходив по хаті, безперестанку човгаючи турецькими патинками, вичитими сріблом [6, 105], де патин$\boldsymbol{\kappa} \boldsymbol{u}$ - „туфлі без закаблуків у деяких східних народів” [2, 710];

9. Назви будівельних споруд і їхніх складових: Невеличкі хати, між котрими було багато мазанок, скрізь розбіглися, як овечки [6, 213], де мазанка - „хата, зроблена з глини, сирцевої цегли або хмизу, обмазаного глиною" [2, 503]; А вони вдвох виходять з повітки чорні, мохнаті та пеле$x a m i[6,369]$, де повімка - „господарське приміщення для утримання свійських тварин або зберігання сільськогосподарського реманенту та різного майна" [2, 813]; Я оступилась під загату, притулилась, голову ховаю під острішок [6, 369], де загата - „стіна хліва, зроблена з подвійного плоту, закладеного всередині соломою” [2, 289], острішок - „солом'яний дашок на загаті" [2, 687]; Хіба ж давно витрусила в його клуні в засторонку копу чужої пшениці, щзо перевіз уночі з чужого поля? [6, 417], де клуня - „будівля для зберігання снопів, сіна, полови тощо” [2, 435], засторонок - „спеціально відгороджене місце у клуні, стодолі"; На острові під кам'яною стіною притулився здоровий питель на два етажі [6, 469], де питель „млин, на якому змелюють біле борошно особливим помолом” $[2,760] ;$... ігумен настановив ї̈ за начальницю монастирської палати [8, 222], де палата - „велике приміщення, призначене для спеціальних цілей; комора” [2, 698]; Мій панотецьь, не чекаючи часу, зараз влітку завів першу в Стеблові школу для селянських дітей в пасіці в катразі [8, 229], де катрага „легка будівля (курінь) здебільшого на пасиці” [2, 421]; Одні великороси неначе вік прожили в скитах [6, 107], де скит - „невеличке житло ченцівсамітників, розташоване віддалік від монастирських будівель " [2, 1135]; Легко й прудко, як та коза, вона вхопилась за кінець сволока, вискочила на сволок і крадькома полізла на горище [6, 446], де сволок - „поперечна балка в деяких спорудах" [2, 1110]; За годину або за дві поперед сього через 
ту саму царину Марина випроводила в дорогу свого москаля [6, 53], де царина - „ворота при в 'їзі в село” [2, 1358];

10. Назви знарядь праці та їхніх складових: Нимидорі здалося, щуо вони самі неначе пороблені з розпеченого червоного заліза, світяться наскрізь, пушать вогнем та все б'ють червоними залізними ціпами по вогняних cнonax [6, 467], де ціn - „ручне знаряддя для молотьби, що складалося 3 довгого держака і прикріпленого до нього ременем або мотузком короткого дерев'яного бича" [2, 1366]; Зараз за током, коло самого панського сад$\kappa a$, молодиці на сонці били на бительнях і тіпали коноплі [6, 453], де бительня - „станок для первинної обробки льону, конопель” [2, 49]; Мичка на гребені світилась наскрізь. Нимидора поклала гребінь на днище й сіла коло його [6, 462], де мичка - „пучок конопель або льону, підготовлений до прядіння” [2, 526], гребінь - „високий дерев'яний стояк із зубцями, що на них насаджувалася пряжа за ручного прядіння” [2, 197], днище - „дошка, у яку закладали гребінь під час прядіння ниток ручним способом" [2, 228]; Терниця гавкала під ї̈ руками, як сучка, дрібно та голосно, аж скрипіла, аж вила... ї̈ руки не переставали ворушити мечик терниці [7, 169], де терниця (терлиця) - „знаряддя для тіпання, тертя льону, конопель” [2, 1241], мечик - ,дерев’яна ударна частина терниці” [2, 523]; Харитін сидів, нахиливши голову й похнюпившись, а думи снувались в його голові, як нитки на снівниці $[7,284]$, де снівниця - „пристрій, на якому снували основу якої-небудь тканини" [2, 1156];

11. Назви предметів побуту: Жарти жартами, а я, їй-богу, трохи чи не правду кажу, щзо не знайдете ні товкача, ні ковганки, бо изі київські ледашииі не затовкують салом борщу $[6,382]$, де товкач - „заокруглений на кінці стрижень, яким товкли, розтирали що-небудь у ступі” [2, 1252], ковганка - „дерев'яна ступка для товчення сала" [2, 437]; Сидів пасинок на призьбі, а вона з сіней итурм його рогачем у спину [6, 416], де рогач - ,довгий дерев'яний держак з двома металевими заокругленими ріжками на кінці, якими брали і ставили в піч або виймали 3 неї горщики, чавуни" [2, 1037]; Скраю на полиці, рядом з горшками, стояла дощечка з невеличким млиновим колесом та ступами [6, 439], де ступа - „пристрій для лущення та подрібнення різних речовин, неодмінним доповненням якого $є$ товкач" [2, 1210]; Дівчина витягла відро води коромислом [6, 437], де коромисло - „дерев’яна вигнута палиця з зарубками або гачками на кінцях, якою носили на плечах відра 3 водою" [2, 456]; Коли ви всі мене товчете, як макогін макітру, як рубель качалку, покину я свого чоловіка [6, 432], де макогін - „дерев'яний стрижень із потовщеним заокругленим кінцем, яким розтирали в макітрі мак, пшоно тощо” [2, 505], макімра - „вид глиняного посуду великого розміру напівсферичної форми 3 широким отвором" [2, 505], рубель - „вузька дерев’яна дошка з ручкою та поперечними зарубками для качання білизни” [2, 1088], качалка - „кругла гладко витесана палиця для розкочування білизни" [2, 421]; А щзоб діжки та кадовби з вари- 
вом наливать [6, 392], де діжка - , невисока широка дерев’яна посудина 3 плоским дном” [2, 227], кадовба (кадіб) - „велика діжка” [2, 409]; Рибу позбирали в здорові шаплики й цебрики, і всі рибалки пішли на пересип до куреня [6, 500], де шаплик - „невисока широка дерев'яна посудина, що має вигляд зрізаної бочки” [2, 1389], цебрик (цебер) - „, велика дерев’яна посудина, що має вигляд зрізаної діжки” [2, 1359];

12. Назви одиниць виміру та ваги: Оддавши ченцеві сувій полотна й карбования, стара Джериха з Нимидорою пішли до церкви на службу [6, 516], де сувій - „шматок полотна певної довжини, що його зберігали згорнутим у трубку" $[2,1212] ;$...вона за ввесь інститутський час $і$ справді випила добру пориію оцтту, схламала потаєнц̧і пудів зо два крейди, щзоб бути блідою й делікатною, як тоді була мода [6, 401], де пуд - „міра ваги, що дорівнювала 40 фунтам (близько 16,4 кг)" [2, 1003]; Він ледве вдержався, щуоб не луснуть Бродовського, і тільки приступив до посесора на ступінь [6, 484], де ступінь - „назва одиниці виміру невеликих відстаней на поверхні землі, що дорівнювала відстані між стопами ніг (приблизно 70-75 см)" [2, 1210]; Міряє, міряє, а піде жати, то й вріжеться на ступінь або й на два в чужу різу [6, 414], де різа - „досить мала, відрізана від великого масиву ділянка землі, яка в різних місцевостях України дорівнювала трьом, шести або десяти моргам (один морг -0,56 га)" [2, 1034]; Кожній молодиці, дівчині, навіть дівчиниі пани накидали прясти на зиму по дві півмітки [6, 454], де півмімка - ,міра пряжі, яка дорівнювала половині мітка (мотка) - 20-30 пасмам"; На качку давали з економіі по гарцеві зерна, але качка за літо здохла б, а не прохарчувалася би тим гарием [6, 456], де гарець - „міра сипких тіл, що становила 3,28 літра” [2, 173] ; Все поле було вкрите копами та стайками, як небо зорями [6, 456], де копа - „стіжок із 60 снопів хліба, складених колоссям усередину й прикритих одним снопом зверху” [2, 453], стайка - ,ряд кіп, полукіпків на полі" [2, 1186]; Тим часом Мина витяг з кишені око горілки й поставив на стіл [7, 94], де око „міра об'єму хмільних напоїв, що приблизно дорівнювала 1-1,5 л” [2, 667];

13. Назви старовинних монет, грошових одиниць: Хлопичі наймали своїм дівчатам музики по три шаги за танец̧ь [6, 40], де шаг - „дрібна розмінна монета вартістю півкопійки; гріш" [2, 1387]; Підросла я, мене один чоловік найняв за няньку за три копи грошей та за сорочку на рік [6, 443], де копа - „одиниця лічби грошей, що дорівнювала 50 копійкам” [2, 453]; Пан Ястиембський, журавський посесор, закликає вас до себе на роботу, дає по восьмигривенику на день на його харчах $[7,9]$, де восьмигривеник „неофіційна назва старої монети вартістю 80 копійок” [2, 159].

У межах кожного лексико-семантичного поля на основі спільних видових ознак (гіперсеми меншого ступеня узагальнення) можна виокремити по кілька (як мінімум дві, а то й більше) лексико-семантичних груп, наприклад, лексико-семантичне поле „Назви одягу та взуття” охоплює такі лексико-семантичні групи, як: а) назви верхнього чоловічого та жіночого 
одягу: На другій стіні висів портрет якогось давнього Сухобруса в кунмуші, з порізаними рукавами накид $[6,116]$, де кунтуш - „верхній розпашний чоловічий і жіночий одяг заможного українського і польського населення XVI-XVIII ст." [2, 473]; Був собі чоловік-нетяжка, а на йому синя семряжка, на голові шапочка, а на спині латочка [6, 219], де семряжка „верхній селянський одяг із домотканого грубого нефарбованого сукна” [2, 1114]; Поруч із ним ішов парубчак в картузі, в крамній сірій козачині, підперезаний червоним поясом [6, 245], де козачина (козакин) - „чоловічий короткий каптан на гапликах із брижами ззаду та стоячим коміром" [2, 438]; б) назви предметів легкого чоловічого і жіночого одягу: Всі дружки були гарно повбирані, в білих сорочках, в горсетах, в стрічках та квітках [6, 189], де горсет (корсет) - „верхній жіночий одяг - безрукавка, пошита в талію з кольорової тканини" [2, 457]; ... тоді вищезли коло гімназї ті карети й фаетони і лакеї в лівреях давніших польських панів [6, 372], де ліврея - „формений, звичайно обшитий галунами (тасьмою), одяг для лакеїв” [2, 489]; А як іде, то запаска на ній так і розійдеться спереду на обидва боки [6, 415], де запаска - ,жіночий одяг у вигляді шматка тканини певного розміру (переважно вовняної), що використовувалася замість спідниці для обгортання стану поверх сорочки" [2, 317]; Лейба вже скинув свій демікотонний шлафрок і вбрався в чорний сюртук [7, 66-67], де шлафрок„домашній халат” $[2,1400]$; в) назви головних уборів: Вже б давно час ій дбати на смерть: готувати ладан, намітку та воскові свічки [6, 427], де намімка - „покривало $з$ тонкого серпанку, яким зав'язували поверх очіпка голову заміжні жінки" [2, 570]; Між молодими студентами, гуляли на алеях професори-ченці в широких чорних шовкових рясах, в високих клобуках [6, 104], де клобук - „високої циліндричної форми головний убір із покривалом для православних ченців" [2, 434]; I, по правді сказавши, тобі така макітра та чалма багато більше прияличувала б, ніж магістерство [6, 389], де чалма - „чоловічий головний убір у мусульман - довгий кусок тканини, обгорнений кілька разів навколо голови; тюрбан” [2, 1370]; г) 스зви взуття: ... моя мати була висока та чорнява, гарна з лиця, кращза од усіх молодиць, скільки я бачила їх на світі, в доброму намисті, в червоній $з$ торочками хустизі на голові та жовтих сап'янцях [6, 443], де сап'янці „чоботи або черевики, пошиті із сап'яну - тонкої м'якої шкіри з козлячих, рідше овечих чи телячих шкур" [2, 1104]; На йому були широкі штани по жовтому полю з темно-червоними, кров'яного кольору вузенькими смужками, пасові чоботи на колодочках [7, 111], де пасові чоботи - „суцільні чоботи з невідрізним передом" [2, 709]. Проілюстровані лексико-семантичні групи за умови виокремлення спільної гіперсеми меншого ступеня узагальнення здатні модифікуватися в напрямку до збільшення їхньої кількості.

Будь-який лексичний архаїзм, як і лексема загалом, характеризується не тільки семантичними, функціональними, але, безумовно, i структурнословотвірними та генетичними особливостями. Одна частина застарілих 
лексем (наприклад, куна, квит, бурлака, чинш, балагула, жсупан, клуня, гарещь, пуд, око тощо) вирізняється своєю словотвірною непохідністю, інша (наприклад, колодка, духівниця, торжск, пірник, панщцина, мичка, днище, терниця, снівниця, товкач, рогач, мазанка, політник, острішок тощо) - репрезентує морфологічний (пірник < перо; товкач < товкти; політник < літо; острішок < стріха і т. ін.), морфолого-синтаксичний (подушне, подзвінне, гуменний, становий, десяцький, кодільничий і т. ін.), семантичний (дуб, метелиця, хрещцк, свинка і т. ін.) способи утворення.

Слід, очевидно, зауважити й на тому, що більшість із лексичних архаїзмів становлять питомий шар української лексики, тобто ці лексеми або успадковані від прамов, або утворилися на власне українському мовному грунті. Деякі з архаїчних лексем спродуковані на основі лексичного матеріалу, успадкованого зі спільносхіднослов'янської, праслов'янської, індоєвропейської мов, за допомогою власне українських словотворчих засобів. Щоправда, унаслідок конвергентних процесів підсистема застарілої лексики значно збагатилася через найрізноманітніші іншомовні запозичення, які відбулися внаслідок сусідства народів, їхніх державних, торговельних та культурних зв’язків.

Так, скажімо, лексема еполети походить від франц. epaulette (одн. epaule - плече) - „погони особливої форми (заокруглені на кінці), прикрашені золотими чи срібними позументами, бахромою тощо” [10, 428]. Стилістичний архаїзм канm походить від лат. cantus - спів, пісня - „жанр давньої одичної поезії, віршований твір, складений з нагоди урочистої події чи свята; хорова пісня без супроводу" [10, 499]. Історизм кантоніст походить від нім. Kantonist < франц. canton - округ - ,у XVII ст. у Прусії так називали рекрутів, яких брали на військову службу з полкових округів" [10, 499].

Твірним для застарілої лексеми академісm послужило слово академія, що походить від лат. Academia < Akadēmeia - „філософська школа, заснована Платоном близько 387 р. до н.е. біля Афін” [10, 39]. Первинно значення цього слова пов'язувалося з назвою місцевості поблизу Афін, яка згідно з легендою, належала міфічному герою Академу.

Лексема фаетон походить від грецьк. Phaethōn <phā̄-,сяю”. У давньогрецькій міфології такий звуковий комплекс використовувався для номінації сина Геліоса, бога Сонця, який випросив у свого батька вогненну колісницю i, не вміючи правити кіньми, ледь не призвів до всесвітньої пожежі, за що й був убитий блискавкою Зевса. Згодом за цим словом закріпилося й ширше значення - ,легковий автомобіль з відкритим кузовом” [10, 921].

3-поміж лексичних архаїзмів можна виокремити ті, які свого часу були запозичені (прямим чи опосередкованим шляхом) із латинської (ревізія < revisio - „Перегляд”; noceciя ‘ possessio - „володіння”; nосесор 〈роssessor - „власник”; naлата < palatium - , палац”; економія < оесопотіа - „правильне господарство” < грецьк. oikonomia - „ведення домашнього господар- 
ства”), грецької (синод < synodos - „сход, збори”), французької (ліврея < livree < лат. libero - „звільняю, даю, захищаю”; zopcem < corset < corps - тіло - „широкий пояс, що стягував нижню частину грудної клітини і живіт, щоб надати фігурі стрункості”; шарабан 〈 char a bancs - „букв. візок з лавками”), німецької (фіжжми ‘ Fischbein - „китовий вус"), тюркської (клобук < kalpak - „шапка"), турецької (чалма < calma - „головний убір”; феска $(\boldsymbol{\phi e c})<\boldsymbol{f e s}$ - „назва міста в Марокко”), італійської (патинки 〈патина く patina - „наліт різноколірних відтінків), іспанської (мантиль < mantilla < лат. mantellum - покривало, плащ - „мереживна біла або чорна жіноча накидка в іспанок, що накривала голову й верхню частину тулуба") та арабської мов (бурнус < вurnus - „плащ із відлогою” - в арабів так називали грубий вовняний плащ, здебільшого білого кольору і з капюшоном).

Отже, різні тематичні (лексико-семантичні) поля і групи лексичних (матеріальних і стилістичних) архаїзмів, репрезентовані творчою спадщиною I. Нечуя-Левицького, віддзеркалюють передусім історичні та культурні надбання українського народу. Подекуди у тканину своїх текстів автор уміло вводить i так звані екзотизми (етнографізми), що, відображаючи життя і побут інших спільнот, засвідчують тісні взаємозв'язки різних націй і народностей.

Творча спадщина видатного класика постачає нам багатющий фактичний матеріал, на основі якого можна узагальнити, систематизувати знання щодо класифікації застарілої лексики як із урахуванням функціональних, так і семантичних особливостей. Вивчення лексичних архаїзмів на матеріалі художнього доробку письменника сприятиме збагаченню словникового запасу учнів, кращому розумінню програмних (і не тільки!) творів.

\section{Література}

1. Бондар О.І. Лексикологія // Бондар О. І., Карпенко Ю. О., Микитин-Дружинець М. Л. Сучасна українська мова: Фонетика. Фонологія. Орфоепія. Графіка. Орфографія. Лексикологія. Лексикографія. - К.: Академія, 2006. - С. 195-294.

2. Великий тлумачний словник сучасної української мови / [упорядн. та гол. ред.: В. Т. Бусел]. - К.- Ірпінь: Перун, 2001. - 1426 с.

3. Єфремов С. Історія українського письменства / С. Єфремов. - К.: Femina, 1995. - C.481-484.

4. Косериу Э. Синхрония, диахрония и история: Пер. с исп. / Э. Косериу // Новое в лингвистике. - М.: Изд-во иностранной л-ры, 1963. - С. 143-343.

5. Муромцева О. І. Нечуй-Левицький в історії української літературної мови / О. Муромцева // Вісник Харківського університету. - Х., 1999. - № 426. - С. 106-111.

6. Нечуй-Левицький I. Твори: В 2-х томах / І. Нечуй-Левицький. - К.: Наукова думка, 1985. - Т.1: Повісті та оповідання. П'єса. -637 с.

7. Нечуй-Левицький I. Твори: В 2-х томах / I. Нечуй-Левицький. - К.: Наукова думка, 1986. - Т.1: Повісті та оповідання. -637 с.

8. Нечуй-Левицький I. Уривки з моїх мемуарів та згадок: В богуславськім училищі / І. Нечуй-Левицький // Н. Є. Крутикова. Творчість I. Нечуя-Левицького (статті та матеріали). - К.: Вид-во АН УРСР, 1961. - С. 205-242. 
9. Русанівський В. М. Історія української літературної мови / В. М. Русанівський. - К.: „АртЕк”, 2002. - С. 241-244.

10. Словник іншомовних слів / [Пустовіт Л. О., Скопненко О. І., Сюта Г. М. та ін.]; за ред. Л. О. Пустовіт. - К.: Довіра, 2000. - 1017 с.

11. Сучасна українська літературна мова: Лексика і фразеологія / за заг. ред. І. К. Білодіда. - К.: Наукова думка, 1973. - 438 с. 